\title{
Study Load at the Beginning of Studies at Military University and Coping Strategies
}

\author{
Jolana Fedorková, Ivana Nekvapilová, Zdeněk Mikulka \\ Department of Leadership, Faculty of Military Leadership, University of Defence in Brno \\ Kounicova 65, 66210 \\ Czech Republic
}

Received: July 23, 2020. Revised: October 5, 2020. Accepted: October 6, 2020. Published: October 6, 2020.

\begin{abstract}
Socio-psychological research on the study load and ways of coping with it is provided to university management by a number of valuable information for improving the educational process and expanding counselling services for students. The aim of the article is to supplement the general knowledge of the structure of the study load and ways of managing it in a specific area of study such as the study of a military university. The article informs about the results of a pilot research carried out on a sample of 254 first-year students of economic-managerial and technical specialization of military studies. The main goal of this research was primarily to verify whether the biggest burden is still the greatest burden on students and military management. Military students differ significantly in their preferred workload management strategies from their civilian counterparts. Data were collected using the usual method for this type of research - the method of questioning, which was implemented through two questionnaires: Questionnaire of stressful situations and standardized questionnaire Stress Management Strategy SVF 78. The first questionnaire was created for this research based on analogy of available questionnaire from a school environment for research in the civilian environment of lower education levels. The results were processed using the program STATISTICS CZ 12, evaluated using relevant statistical methods (Anova, Mann-Whitney test). Based on the results, the validity of the general assumption could not be proved, as the greatest burden of probands saw in the organizational provision only parts of military education, for which the specific organizational unit of the school is responsible. Positive findings include a preference for positive strategies for managing the military study load over negative ones, in which military students agree with civilian students. For military students, compared to the assumptions,
\end{abstract}

statistically significant differences in the use of some strategies depending on gender were demonstrated; differences depending on the field of study could not be demonstrated. Despite the local validity of specific results, the text can be beneficial for a wider academic environment both in the field of methodology and knowledge.

Keywords-Coping Strategies, Military Higher Education, Study Load, Tertiary Education.

\section{INTRODUCTION}

$\mathrm{T}$ HE study load and the student's ability to manage it have been identified in a number of studies carried out at Czech civilian universities [1]-[6] as well as the foreign one [7]-[11] as one of the important factors determining whether a student completes the studies he has started or not. The mentioned researches bring other important findings for the implementation of research of study load in the university environment. The ability to manage the study load develops throughout the period of adolescence. This period is perceived as crucial in the development of the strategy of coping with a study load [12]. We consider that each person modifies his/her own strategies based on previous experience.

It has resulted from the statistics that the biggest problems with managing the university study load are in the first phase of study. It represents about half of all study failures [13]. It can therefore be assumed that the knowledge of the study load at the beginning of the study for all students should help the educational institution to more precisely target the assistance to students in managing the study load and, above all, to allocate the load appropriately during the study. 
If the only military university in the Czech Republic - the University of Defence - focuses on the training of future officers, specialists and staff officers has long faced the problem of early school leaving, it should be focus on a comprehensive examination of the study load and ways of managing it, especially in the beginning of their studies.

However, the fact is that in the Czech military university environment a high percentage of unfinished studies is traditionally attributed only to a partial part of the study load, especially to the demanding and demands of military service and physical and mental stress [14] [15] which is directly related with them. In the past, data collection was performed on a small specific sample of students, consisting of those who had already decided to terminate their studies. Such an approach did not allow to obtain a comprehensive view of the study load in the current conditions of military higher education. Logically, therefore, he could not provide enough information to the educational institution to solve a burning problem - the increase in prematurely completed studies.

With the intention of arranging a remedy in the area in question and also finding out what is the situation at other military universities abroad, with which the Czech military educational institution could compare and also be inspired, a specific research of the Ministry of Education, Youth and Sports was created. It is entitled Experience of Foreign Military Universities with Early Termination of Studies (SV19-FVL-K104-FED).

The present study is one of its current outcomes. Its aim is to inform about the results of the pilot quantitative research focused on identifying stressors that affect a student of a military university, about the intensity of perceived load and the military students' strategies of coping with stressful situations at the beginning of studies.

It consists of three parts. The first - theoretical background - summarizes relevant theoretical knowledge for research of study load at a military college with the intention to describe this specific area of study load and find a suitable tool for its measurement, then identify a suitable tool for identifying strategies for managing study load. The second part of the study describes the methodology of the pilot research in more detail and the third part contains the results and their interpretation.

\section{THEORETICAL BACKGROUND OF THE INVESTIGATED PROBLEM}

Since 1999, the study load has been defined to some extent by the Academic Credit System on the basis of the Bologna Declaration [16]. In this context, the student's performance aspect is assessed by the number of credits obtained. According to experts, every university today should not only be interested in whether students have obtained the appropriate number of credits, but how they obtain them, what efforts they must make to obtain them, because it is in these areas that researchers identify the main reasons for students to decide early end. Answers to such questions are provided by a sociopsychological view of the study load [17], which puts the student and his abilities in the spotlight, where it is true that the individual's success to cope with study conditions is determined by his ability to manage stress. In this context, many universities mention an increase in the prevalence of reported stress, anxiety and depression among university students [18] [19]. For the military university environment, such mental states of students are undesirable not only in connection with the decision to terminate their studies prematurely, but mainly because they could bring significant security risks for the students themselves, as military training involving weapons is conducted during their studies.

\section{A. Study Load at Military University}

In general, in a socio-psychological approach, stress is considered a situation that goes beyond the daily experience that causes stress. It is an individual's response to a new stimulus and the search for new patterns of adaptation, from which stereotypes of behaviour are created. The study load in this approach is represented by the demands of study [20] [21].

How to specify the requirements of university studies in order to measure the intensity of their impact on the student? The foundations are provided by the methodology of Hodges and Felling [22] and Yungman [23], thanks to which a number of items of school workload observed in the civilian environment [24]-[27] were identified. Significant inspiration can be found in the categorization of school stressful situations according to Binarová [28]. It was used in the Questionnaire of the Stress Situations, which was created by the members of the Department of Psychology and Pathopsychology of the Faculty of Education, the Palacký University in Olomouc [29] [30]. The questionnaire works with the division of study stressful situations into areas related to performance (learning and performance conditions), to interpersonal relations (teacherstudent, mutual relationships among classmates) and evaluation (the process and outcome of school assessments). According to Plevová, Urbanovská and Binarová [30], stressful situations can also play a role in others, including physical conditions of study.

In the military university environment, it is necessary to connect them with military training in the field and the military way of organizing students' lives, relations not only with teachers, but also with commanders of school units. The status of a military university student is already different at the beginning of his/her studies. A military student becomes a professional soldier after taking an oath at the beginning of his/her studies. The special characteristics of his/her service relate to the restriction of certain civil rights, observance of military orders, discipline, wearing a military uniform, accepting the obligation to serve his/her country and to participate in its defence - all in accordance with the militarypolitical ambitions of the Czech Republic resulting from its NATO membership. He/she must identify himself/herself with 
these aspects and accept the demands of the military environment, including study obligations. With regard to a number of peculiarities, it is possible to call the set of all activities including the educational ones that a student must fulfil in a military environment as a military study load.

As the researches show, the ability to manage the study load at a university can be influenced by a number of individual and social factors. The individual factors include the ability to mentally assess the situation or tendencies to emotional irrational reactions to change, the individual's adaptability to a new environment, the ability of self-regulation combined with the ability to manage their own time, attitude to study and study habits [31]. Some study stressful situations may also arise based on the individuals' own ideas and negative scenarios, when impulses that do not distinguish the idea from reality are transmitted to the brain. The stress reaction can have its inner impulse, it can be triggered by thinking. Social factors include the situation in the family, the need for independent living, the need for social contacts, etc. In the military environment, the degree of identification with the values and rules accompanying the military profession, the social status of this profession also plays an important role.

Although opinions differ on the strength of these factors according to some researchers, stress is caused by structural conditions rather than by the student's personality [32] it is necessary to assess each case of extreme mental stress individually, because it arises from a specific combination of different factors and has its own genesis. Whether and how students are able to cope with workload can be partly indicated by their knowledge of their coping strategies of study load.

\section{B. Coping Strategies of Study Load}

According to Lazarus and Folkman [33], coping is defined as a process that occurs in response to a given situation, in which an individual tries to change the relationship between the stressor and himself/herself to make the situation less stressful. It is therefore a conscious and deliberate effort, which includes all attempts to manage stress - a cognitive or behavioral effort to reduce the effects of excessively high demands on study stressful situations, or, conversely, conscious adaptation to the stressor.

The ways in which an individual consciously tries to cope with stress are referred to as coping strategies. W. Janke and G. Erdmann [34] understand coping strategies as psychic processes that occur when stress is created in order to alleviate or end it. It is a kind of response to stress leading to the achievement of the initial psychosomatic level, possibly to avoid a larger deviation from the initial state. The authors assumed that the ways of processing stress are so aware that it is possible to ask about them. They understand them as habitual personality traits - that is, as relatively stable over time and relatively independent of the type of stressful situation. They believe that when researching coping strategies, it is necessary to respect the factor of situational conditionality and define the situational aspect, which in this case is the study load.

The identification of individual strategies is based on both the transactional and interactive model of the concept of stress [35]. An assumption of cognitive evaluation and perception of stressors is accepted from the transactional model; the stressors influence the subsequent selection of a coping strategy and are the basis of the work concept. The interaction model of situation and personality conditions is taken over from the interaction model of the concept of stress, ie. cognitive evaluation, personality characteristics and situational variables [36] [37].

In general, coping with stressful situations is aimed at a problem / situation as well as emotions. Some authors also distinguish the third group - avoidance coping. Instead of facing a stressful event, an individual looks for the ways to avoid it - e.g. distraction or amusement [38]. Lazarus [39], Pennebaker [40], Nolen-Hoeksema et col. [41], focus on managing negative emotions. The authors agree on the strategy of seeking emotional support in other people and getting rid of the problem. Positive social support can also help in better emotional adaptation to stress, by preventing constant rumination by stressors. People who experience a ruminative coping style work less commonly on an active solution induced by a stressor. On the other hand, people who use pleasant activities to relax for a while, more often turn to an active solution [42]. Displacing negative emotions from consciousness - the maladaptive way - may not always lead to success and can have a certain negative impact on health.

Individual coping strategies usually either increase stress (e.g. Resignation or Self-accusation) or reduce stress (e.g. Underestimation). Those strategies that reduce stress are referred to as positive, those that increase it as negative. Individuals differ in their use [34] [43]. Although the proven difference in using both of them among university students was not noticeable [44] [45] the using of positive strategies should be desirable for successful management of study load, as proactively managed stress emphasizes stress management and is associated with positive emotions in the process load management [46].

Creating positive ideas and scenarios about coping with a stressful situation facilitates adaptation in challenging stress conditions [47] [48]. The positive stress management scenarios are also a source of relief from anxiety [49], a source of new energy [50] and a new meaning of stressful conditions [51]. The topicality of these findings is increasing in relation to the current Generations Y and Z, for whom the declining ability of resilience - resistance to stress has been demonstrated [52].

Numerous research studies have shown that strategies change in students according to the level of anxiety [53], extraversion and neuroticism [54], assuming a certain individual stability in the preference for coping activities, differentiation and use [55]. The age also plays a role. 
Shiraishi and Aldwin [56], assumed the existence of changes in coping in early adulthood. The data collected over a 5 -year period showed a reduction in negatively oriented strategies, such as lying, inducing others to feel guilty, or manifestations of resistance. The ability to choose an effective strategy is lower in adolescents in comparison with adults, which is obviously given by less experience [57]. Other influences such as exam preparation, university adaptation, self-esteem, optimism and psychological control cannot be neglected [58].

\section{RESEARCH METHODOLOGY}

The analysis of available information sources showed that reliable data on the study load of students with a military degree cannot be obtained from the research of the study load of university students, as this group was not included in the research samples at all. Related to this was the absence of a tool to map what situations are perceived as stressful for students in a military university environment and what intensity of stress they cause them. In addition, a series of interviews with students who decided to drop out of their studies prematurely led to the reasonable assumption that they no longer place the greatest burden on students for military activities and their successful management, as was generally assumed.

In order to find out the causes of the high number of prematurely completed studies of the military university in the field of military study load and obtain information about it in connection with the planned changes in the concept of fiveyear military study program (SP 2014), it was necessary to prepare own research to determine the intensity of perceived stress in the areas of study load in the students of the $1^{\text {st }}$ year of military university and to determine what stress management strategies these students prefer.

The pilot study, the results of which are presented in the article, was carried out on a sample of 254 students from two main profiles of military studies - economic-managerial and technical. The respective faculties are responsible for individual study profiles - the Faculty of Military Leadership (Czech abbreviation: FVL) and the Faculty of Military Technology (Czech abbreviation: FVT).

The quantitative research design was chosen due to the need for comprehensive mapping of stress areas with respect to the profile and year of study and the identification of the predominant strategies for managing the study load. The structure of the sample, in which women are also represented, can also provide partial information on the differences in the perception of workload and coping strategies between men and women. Due to the fact, that in the military university environment, the largest number of prematurely completed studies has long been recorded in the first year of study, the attention of researchers was focused firstly on this year. These facts are also limiting factors of the pilot study.

\section{A. Research Objectives and Hypotheses}

The research had two important goals. The first of them was to find out what situations (list of areas $A-G)^{1}$ are perceived as stressful for students of the $1^{\text {st }}$ year of a continuous five-year military study program in two specializations and whether they differ significantly in the degree of stress. The second research goal was to determine the preferences in the use of strategies for managing the study load of military students, to verify whether they differ from the population standard.

The following hypotheses have been formulated in relation to the first goal:

$\mathrm{H}_{1}$ : The mean values of stress intensity are the same for the individual areas of military study load in $\mathrm{A}-\mathrm{G}$ items.

$\mathrm{H} 1_{\mathrm{A}}$ : The mean values of stress intensity are not the same for the individual areas of military study load in $\mathrm{A}-\mathrm{G}$ items.

In relation to the second goal hypotheses have been formulated in a shortened form, they relate to the preferred stress management strategies - the study load, where $\mathrm{X}$ is always a specific strategy ${ }^{2}$.

$\mathrm{H} 2_{0}$ : The mean values (population medians) of the utilization rate of X strategy are the same for men and women.

$\mathrm{H} 2_{\mathrm{A}}$ : The mean values (population medians) of the utilization rate of X strategy vary for men and women.

$\mathrm{H} 3_{0}$ : The mean values (population medians) of the utilization rate of X strategy are the same for the fields of the Faculty of Military Leadership and the Faculty of Military Technology. $\mathrm{H} 3_{\mathrm{A}}$ : The mean values (population medians) of the utilization rate of X Sdiffer for the fields of the Faculty of Military Leadership and the Faculty of Military Technology.

\section{B. The Characteristics of the Research Sample}

A total of 254 students whose started the $1^{\text {st }}$ year of their studies in the academic year 2018/2019 of the Faculty of Military Leadership and the Faculty of Military Technology of the University of Defence were included in the sample. The distribution of the sample was not uniform in terms of the observed characteristics - study profile, gender of respondents. Due to the two dates of data collection, the number of respondents who filled in the different types of questionnaires differed. Some questionnaires were filled in incorrectly and had to be excluded from the research file.

For the Stress Situation Questionnaire, data were evaluated for 240 respondents ( 114 men and 34 women of FVL, 82 men and 10 women of FVT), for the Coping Strategies Questionnaire data were evaluated for 248 respondents (122 men and 34 women of the FVL and 80 men and 12 women of the FVT). The age spread of respondents was from 19 to 28

\footnotetext{
${ }^{1}$ A: Teacher - Student Relationship, B: School Assessment, C: Military Training - C1 Field Training, C2 Military Duties / Matters, D: Learning Process Conditions, E: Students' Interpersonal Relationships, F: School Regiment, G: Other Factors.

2 POS 1 - Underestimation, Guilt Rejection, POS 2 - Diversion, Substitutional Satisfaction, POS 3 - Situation Control, Reaction Control, Positive Self-instruction. NEG - Escape Tendency, Perseverance, Resignation, Self-accusation. Need for Social Support, Avoidance.
} 
years ${ }^{3}$. Data collection took place in the academic year 2018/2019, in January 2019 in two terms at the end of the winter semester within the Leadership course in standard conditions in the form of pencil-paper. The survey was voluntary and anonymous. The respondents were duly acquainted with the purpose and their rights by the administrator.

\section{The Characteristic of the Methods Use}

The main method for identifying the strategies for stress management in the area of study load was a questioning method, which was implemented through two questionnaires with regard to the sample size.

The first of these had to be created for research purposes. It was given the working title of the Questionnaire of Stressful Situations at the University of Defense. It was inspired by the Questionnaire of the Stress Situations, which was created by members of the Department of Psychology and Pathopsychology of the Faculty of Education, the Palacky University in Olomouc and it was verified in their researches [29] [30].

To complete the questionnaire items related to the special characteristics of the military environment the results of periodic / motivational interviews with the students of the $1^{\text {st }}$ $3^{\text {rd }}$ years since 2015 (ca. 600 students) have been used together with the discussions with the students and consultations with the workers of the Centre of Counselling Services. They always monitor the reasons for early termination of studies in the students leaving university. Thus, the original questionnaire was extended to 103 items of a possible study load in the military university environment. The study load factors were divided into eight areas (Teacher - Student Relationship, School Assessments, Military Training - Field Training, Military Duties / Matters, Learning Process Conditions, Students' Interpersonal Relationships, School Regiment, Other Factors marked as A - G). The individual areas were specified in more detail and they were divided into specific items:

\section{A: Teacher - Student Relationship}

The items relate to e.g. praises, ridicule, humiliation, punishments, the organization of lessons by the teacher, testing - the stressful situations arise from the perception of the student as a personality (creating distinctions between good and not very successful students, privileges, the teacher' preferences for the student, not accepting an opinion or not appreciating efforts). This category also includes stressful situations that arise from the insufficient organization of classes by an academic worker - a professional soldier or a civilian teacher).

\footnotetext{
${ }^{3}$ The age spread of students - 9 years - results from the individual's prior practice before entering military university. There is a group of students, who will begin their studies at the University of Defence immediately after completing the secondary school / grammar school. Further, those who have studied at another university that they have completed or interrupted. Some students exercised their professions before starting their studies.
}

\section{B: School Assessments}

Stressful situations fall into the area of school assessments. They are related to the interpretation and commentary of the study performance assessment, the assessment of the student within exercises and final seminars, which come after the lectures and require the knowledge of the subject of study continuous passing of tests and the learning outcomes. These are also stressful situations arising based on the acquisition of a large amount of knowledge in a relatively short period of time, situations resulting from the insufficient fulfilment of the student's duties (poor arrangement of priorities of study obligations) - the elaboration of assignments and the presentations of final credit papers, examinations.

\section{C: Military Training - C1 Field Training, C2 Military Duties / Matters}

The activities related to the student's military specialized training fall into this area - theoretical combined arms training in gunnery, monkey motions and medical training, NBC defence, the knowledge of basic orders and duties of a military professional. Theoretical lessons precede practical training, which is held for the students of the $1^{\text {st }}-3^{\text {rd }}$ year of study in the Březina Military Training Area in the Vyškov garrison (Field Training), where attention is paid to military drills at the level of an individual, squad, platoon, commander's position.

\section{D: Learning Process Conditions}

The conditions relate to the physical and social environment of the University of Defence - the study facilities intended for teaching in the Brno garrison.

\section{E: Students' Interpersonal Relationships}

The items point to relationships in the collective - the relationship of an individual and a team, competition, the position of a student who holds the leading position of a commander or a deputy commander of the platoon. Indicators are not only the cooperation of students and the assistance in coping with the conditions and requirements of the military study load, but also competition, rivalry or hostile relations.

\section{F: School Regiment}

The factor influencing the study load of students of the University of Defence is an organizational unit - the school regiment - that comprehensively manages, organizes and secures students of military studies. It is responsible for maintaining discipline, daily military life routine, the implementation of service duties as well as the solution of personal matters, including the involvement of students in educational, training and social activities. It is located in the barracks - at the student quarters. It influences the development of the personality and the competencies of military professionals, and forms the moral, ethical attitudes and values of a member of the Armed Forces of the Czech Republic.

\section{G: Other Factors}

This area includes e.g. moves to school, independent work. The category is related to stressful situations affecting the student's state of health, psychophysical condition and wellbeing, which are a condition for fulfilling the duties of a student - professional soldier. 
For individual items, the respondents had the task on a fivepoint scale (1-5) to indicate a value corresponding to the strength of negative feelings - fears - if they experienced such an event or imagine its experience. A value of 1 expressed none stress, 2-low/moderate, 3-mean, 4-considerable, 5-strong stress. Thus, the higher the value, the higher the level of perceived stress.

Preference for using the strategies to manage the study load was investigated in military students through the Coping Strategies Questionnaire - SVF 78. The reason for the selection of the questionnaire was its informative value in accordance with both positive (POS) and negative (NEG) strategies to manage a study load by an individual and the possibility of identifying respondents' approaches to specific counselling work with the student. The questionnaire items relate to 13 scales that specify individual stress management strategies (specified in section 1.2 of this article). The coping strategies are divided into positive and negative ones; each strategy contains 6 items. The maximum raw score that can be achieved within one strategy is 24 .

There are three types of overall positive stress management strategy: POS 1 - Underestimation and Guilt Rejection, POS 2 - Diversion and Substitutional Satisfaction, POS 3 - Situation Control, Reaction Control and Positive Self-instruction. The negative strategies include the following: Escape tendency, Perseverance, Resignation and Self-accusation. In addition to defining positive and negative strategies, the questionnaire also contains two more strategies - Need for Social Support and Avoidance. Janke and Erdmann [59] report that the last two strategies are less prevalent. However, to mitigate the urgency of the problem, e.g. through the psychological support of friends or postponing the problem temporarily are examples of many cognitive or behavioural ways of managing negative emotions [60].

Adequate statistical methods were used for data processing. The intensity of study load for individual monitored areas (A, $\mathrm{B}, \mathrm{C} 1, \mathrm{C} 2, \mathrm{D}, \mathrm{E}, \mathrm{F}, \mathrm{G})$ was calculated as the average value of assigned points for the area. The standard deviation was calculated to assess the variability of the statements. ANOVA with repeated measures was used to determine statistically significant differences between individual areas. The paired ttests with a level of significance adjusted according to the Holm-Bonferroni method were applied as post-hoc tests. The mean and standard deviation were calculated for the compared groups.

Descriptive statistics was used to identify the preferences of stress management strategies to determine the resulting $p$-value - the two-sample t-test and the Mann-Whitney test (a nonparametric test of the null hypothesis). It is often used when the assumptions of the independent samples t-test are violated. At this time, the Mann-Whitney test was used to compare the utilization rate of stress management strategies based on genders and the specialization since the assumption of normal distribution was violated in all strategies according to the Shapiro-Wilk test (a test of normality in frequentist statistics). The test rejects the hypothesis of normality when the p-value is less than or equal to 0.05 . Failing the normality test allows you to state with $95 \%$ confidence the data does not fit the normal distribution. Passing the normality test only allows you to state no significant departure from normality was found. The mean and standard deviation were calculated for the compared groups. All calculations were performed using STATISTICA CZ 12 a comprehensive analytical tool for data management and processing in all areas of human activity. The statistically significant correlation coefficients were determined at the significance level of 0.05 .

\section{DESCRIPTION AND INTERPRETATION OF RESEARCH RESULTS}

Due to the clarity and easier interpretation of the results, the data related to the study load and the strategies to cope with it was evaluated in the order of formulated hypotheses (see chapter 2.1.).

\section{A. Intensity of Perceived Stress in Areas of Military Study Load}

Table 1 presents a comparison of the lowest and highest intensity of the perceived stress that students experience in the areas of the military study load. Box Plot 1 shows the median, lower and upper quartile, minimum and maximum for all compared areas. The overall highest measured value of the intensity of perceived stress was not found in areas directly related to military training $(\mathrm{C} 1, \mathrm{C} 2)$, but in area F: School Regiment. The second in the order of intensity of activity was area (B) - the area of Evaluation of Study results and Student Performance - school classification. Only the third position is occupied by military training during the study. The lowest intensity was found in area D: Learning Process Conditions.

According to the standard deviation, it can be concluded that students tend to agree on this order, as no high variability was found in these areas. According to the standard deviation, the highest variability of responses was found out in the area of Students' Interpersonal Relationships, which may be completely natural, as this is the area that is most dependent on the subjective attitudes and evaluations of the respondents. The lowest variability of responses was found out in the areas of Military Duties / Matters, School Assessments and Other Factors. The p-value for the null hypothesis testing was based on ANOVA with repeated measurements with respect to 3 decimal places $(0.000)$, i.e. less than 0.05 . At a significance level of 0.05 , it was proved that the mean values of stress intensity were not the same for all stress areas. The null hypothesis was rejected in favour of the alternative one.

Table 1: Intensity of perceived stress in the areas of study load

\begin{tabular}{|l|c|c|c|c|}
\hline Stress area & Mean & SD & p-value & $\begin{array}{c}\text { Decision on } \\
\text { H1 }\end{array}$ \\
\hline $\mathbf{A}$ & 2.85 & 0.63 & 0.000 & rejected \\
\hline
\end{tabular}




\begin{tabular}{|l|l|l|l|l|}
\hline B & 3.09 & 0.55 & 0.000 & rejected \\
\hline C1 & 2.95 & 0.68 & 0.000 & rejected \\
\hline C2 & 2.88 & 0.54 & 0.000 & rejected \\
\hline D & 2.64 & 0.69 & 0.000 & rejected \\
\hline E & 2,76 & 0.86 & 0.000 & rejected \\
\hline F & 3.37 & 0.66 & 0.000 & rejected \\
\hline G & 2.67 & 0.57 & 0.000 & rejected \\
\hline
\end{tabular}

Source: Data source - the authors' own calculations

All pairs of areas were subsequently compared based on post-hoc paired t-tests with the Holm-Bonferroni correction of a significance level (the number of comparisons is the binomial coefficient 8 over 2 , i.e. $8 \times 7 / 2=28$ ). The intention was to find out the difference in the intensity of perceived stress in comparison of individual areas. At a significance level of 0.05 , a statistically significant difference was found among 21 pairs of areas.

The comparison showed that the intensity of stress in the area of Military Duties / Matters is, in terms of statistics, significantly higher than the area of Students' Interpersonal Relationships, whereas in the mean value it is a difference in the interval of 0.04 to 0.20 points (on a 1-5 scale) with reliability of 0.95 . The stress intensity in the area of Field Training is, in terms of statistics, significantly higher than in the area of Students' Interpersonal Relationships, whereas in the mean value it is a difference in the interval of 0.08 to 0.29 points (on a 1-5 scale) with reliability of 0.95 . The intensity of study load in the area of School Assessments is, in terms of statistics, significantly higher than in the area of Field Training, whereas in the mean value it is a difference in the interval of 0.06 and 0.21 points (on a 1-5 scale) with reliability of 0.95. The stress intensity in the area of School Assessments is, in terms of statistics, significantly higher than in the area of Teacher-Student Relationship, whereas in the mean value it is a difference in the interval of 0.18 and 0.29 points (on a $1-5$ scale) with reliability of 0.95 . For the remaining 7 pairs, the significance level of 0.05 was not statistically significant.

Box Plot 1: Comparison of the stress intensity in individual areas of the study load

Stress level (1-5)

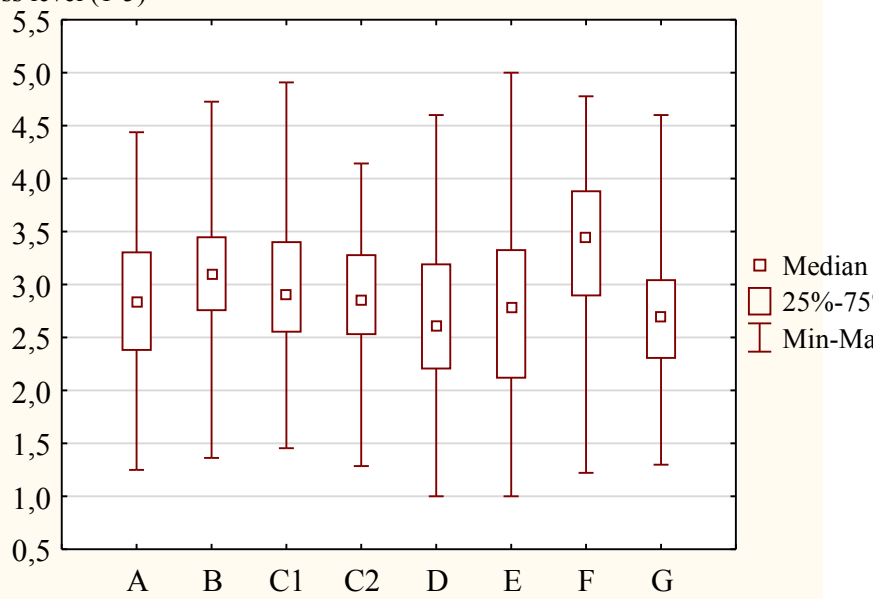

Source: Data source - the authors' own elaboration

Table 2: Situations of study load according to the perceived stress intensity

\begin{tabular}{|c|c|c|}
\hline $\begin{array}{c}\text { Situation } \\
\text { Number }\end{array}$ & Situation Name & $\begin{array}{l}\text { Mean } \\
\text { Value }\end{array}$ \\
\hline $103 \mathrm{C} 2$ & $\begin{array}{l}\text { Dismissal of a professional soldier } \\
\text { from the service. }\end{array}$ & 4.43 \\
\hline $100 \mathrm{C} 1$ & Ignorance of the Field Training Plan. & 4.38 \\
\hline 102B & $\begin{array}{l}\text { Failure in the studies at the University } \\
\text { of Defence. }\end{array}$ & 4.31 \\
\hline 11B & $\begin{array}{l}\text { Incorporation in the field of study } \\
\text { that will not fit your ideas and plans. }\end{array}$ & 4.18 \\
\hline 35B & Failure in exams and credits. & 4.03 \\
\hline $10 \mathrm{~F}$ & $\begin{array}{l}\text { Activities of the School Regiment } \\
\text { after } 4 \text { p.m. }\end{array}$ & 3.87 \\
\hline $4 \mathbf{F}$ & $\begin{array}{l}\text { Company Commander / School } \\
\text { Regiment member humiliates you in } \\
\text { front of other students. }\end{array}$ & 3.79 \\
\hline 25B & $\begin{array}{l}\text { You have to learn a lot of lessons for } \\
\text { the next day. }\end{array}$ & 3.68 \\
\hline 53F & $\begin{array}{l}\text { Your superior (professional soldier) / } \\
\text { school regiment member admonishes } \\
\text { and punishes you for no reason. }\end{array}$ & 3.66 \\
\hline $91 G$ & Lack of time to rest and relax. & 3.60 \\
\hline 8B & Too long time of direct instruction. & 3.59 \\
\hline $\mathbf{3 A}$ & $\begin{array}{l}\text { The teacher humiliates you and } \\
\text { ridicules you in front of the whole } \\
\text { platoon. }\end{array}$ & 3.54 \\
\hline $26 \mathrm{~F}$ & $\begin{array}{l}\text { The student is evaluated within the } \\
\text { school regiment according to a liking } \\
\text { and not according to a job well done. }\end{array}$ & 3.53 \\
\hline $55 \mathrm{C} 2$ & $\begin{array}{l}\text { The superior (professional soldier) } \\
\text { breaks a promise. }\end{array}$ & 3.52 \\
\hline
\end{tabular}

Source: Data source - the authors' own elaboration

In addition to the overall data, the evaluation of the Stress Situation Questionnaire at the University of Defence provided more specific data on stress situations with the evaluation of average values for individual situations in the monitored areas. The intensity of stress perception in a stressful situation ranges from 1.77 to 4.43 , which corresponds to a range from "slightly to considerably". Table 2 presents the situations arranged according to the stress intensity perceived by a student as "considerable or strong", or it is above the half of the mean stress perception, i.e. the intensity of the study load is considered to be higher than the mean value of 3.5.

\section{B. Strategies for managing military study load}

The overall results and comparison with the age-similar cohort of students in the civil sector and the population norm are shown in table 3. The data obtained by means of descriptive statistics are broken down into the categories female and male. For an approximate comparison of the preferences of the strategies used, the raw score averages of 
the population aged 20-34 years are given, including the upper and lower limits of this standard.

As the results show, one of the positive findings is that, overall, military students, regardless of gender, prefer positive strategies to negative strategies, more so than their peers at civilian universities. Among the unclassified strategies - the need for Social Support and Avoidance (5.66 points more for women, 4.26 points more for men) - respondents noted differences between men and women and a tendency to use more often than for civilian peers. According to the results, they are more preferred by military students.

Table 3: Preferences of stress management strategies and an approximate comparison with the population standard according to the average raw scores

\begin{tabular}{|c|c|c|c|c|c|c|c|c|}
\hline \multirow[t]{2}{*}{ Strategies } & \multicolumn{2}{|c|}{ Female } & \multicolumn{2}{|c|}{ Male } & \multirow[b]{2}{*}{$\begin{array}{c}\begin{array}{c}\text { Average } \\
\text { of RSs }\end{array} \\
\text { (population } \\
\text { standard } \\
20-34 \\
\text { years) }\end{array}$} & \multirow{2}{*}{$\begin{array}{c}\text { Standard } \\
\text { upper } \\
\text { limit }\end{array}$} & \multirow{2}{*}{$\begin{array}{c}\text { Standard } \\
\text { lower } \\
\text { limit }\end{array}$} & \multirow[t]{2}{*}{ SD } \\
\hline & Mean & SD & Mean & SD & & & & \\
\hline Underestimation & 11.2 & 5.7 & 13.5 & 4.2 & 10.42 & 15.13 & 5.71 & 4.26 \\
\hline Guilt rejection & 9.9 & 3.8 & 10.9 & 3.6 & 10.98 & 14.20 & 7.76 & 3.62 \\
\hline Diversion & 15.1 & 3.8 & 12.5 & 3.3 & 11.36 & 19.29 & 3.43 & 3.15 \\
\hline $\begin{array}{l}\text { Substitutional } \\
\text { Satisfaction }\end{array}$ & 12.1 & 4.6 & 10.7 & 4.6 & 10.02 & 14.76 & 5.28 & 5.00 \\
\hline Situation Control & 16.7 & 3.4 & 16.1 & 3.7 & 16.84 & 20.18 & 13.50 & 3.61 \\
\hline Reaction Control & 16.3 & 3.4 & 16.3 & 3.4 & 14.82 & 18.92 & 10.72 & 3.64 \\
\hline $\begin{array}{l}\text { Positive Self- } \\
\text { instruction }\end{array}$ & 18.1 & 3.6 & 16.8 & 4.0 & 16.31 & 19.69 & 12.93 & 4.03 \\
\hline POS & 14.2 & 2.4 & 13.8 & 2.4 & 12.46 & 14.89 & 10.03 & 2.24 \\
\hline POS 1 & 10.6 & 4.0 & 12.2 & 3.1 & 10.7 & 14.10 & 7.39 & 3.44 \\
\hline POS2 & 13.5 & 3.5 & 11.7 & 3.5 & 10.69 & 14.26 & 7.12 & 3.44 \\
\hline POS3 & 16.9 & 3.0 & 16.3 & 3.2 & 15.99 & 18.99 & 12.99 & 2.98 \\
\hline Social Support & 15.5 & 4.7 & 12.6 & 4.9 & 13.22 & 18.29 & 8.15 & 4.91 \\
\hline Avoidance & 16.3 & 4.3 & 14.9 & 4.3 & 10.64 & 15.34 & 5.94 & 4.28 \\
\hline Escape Tendency & 8.9 & 4.0 & 8.2 & 3.9 & 7.47 & 11.65 & 3.29 & 5.03 \\
\hline Perseverance & 12.0 & 5.8 & 11.1 & 4.7 & 14.58 & 19.5 & 9.66 & 4.40 \\
\hline Resignation & 8.1 & 3.7 & 7.2 & 3.6 & 8.02 & 11.74 & 4.30 & 4.33 \\
\hline Self-Accusation & 11.0 & 4.5 & 9.9 & 4.1 & 10.6 & 14.72 & 6.48 & 4.35 \\
\hline NEG & 10.0 & 3.7 & \begin{tabular}{|c|}
9.1 \\
\end{tabular} & 3.2 & $\begin{array}{l}10.17 \\
\end{array}$ & 13.30 & 7.04 & 3.42 \\
\hline
\end{tabular}

Both sexes preferred among positive strategies the strategy of Positive Self-instruction, where the values of average gross scores (for women exceeded the limit of 18) tended to approach the upper limit of the population norm. Students also showed significant preferences in the strategies of Situation Control and Control of Reactions. All belong to the group of active positive ways of coping with stress - POS3.

The military students did not differ fundamentally in their overall values from their peers in the use of negative strategies. From this group of strategies, the largest difference was noted between soldiers - students and the norm of the general population in the strategy of Perseveration. The least used strategies in this group were Resignation and Escape Tendency. These strategies tended to the lower limit of the population norm.

As table 4 shows, statistically significant differences in the adaptive behaviour of men and women in situations of increased study load associated with military higher education have been demonstrated only in some strategies. In this table, the p-value of the tests is highlighted in bold; the tests (with regard to the assumption of a normal distribution for the decision on the null hypothesis) were preferred in accordance with rejecting the hypothesis that the median values (population medians) of X strategy utilization rate are the same for males and females. $\mathrm{X}$ is always followed by a specific strategy from table no. 4 .

Table 4: Identification of stress management strategies based on genders

\begin{tabular}{|c|c|c|c|c|c|c|c|}
\hline \multirow[t]{2}{*}{ Strategies } & \multicolumn{2}{|c|}{ Female } & \multicolumn{2}{|c|}{ Male } & \multirow{2}{*}{$\begin{array}{l}\text { t-test } \\
\mathrm{p} \text { - } \\
\text { value }\end{array}$} & \multirow{2}{*}{$\begin{array}{l}\text { M-W } \\
p- \\
\text { value }\end{array}$} & \multirow{2}{*}{$\begin{array}{c}\text { Decision } \\
\text { on } \mathrm{H2}_{0}\end{array}$} \\
\hline & Mean & SD & Mean & SD & & & \\
\hline Underestimation & 11.2 & 5.7 & 13.5 & 4.2 & 0.013 & 0.002 & rejected \\
\hline Guilt rejection & 9.9 & 3.8 & 10.9 & 3.6 & 0.100 & 0.026 & rejected \\
\hline Diversion & 15.1 & 3.8 & 12.5 & 3.3 & 0.000 & 0.000 & rejected \\
\hline $\begin{array}{l}\text { Substitutional } \\
\text { Satisfaction }\end{array}$ & 12.1 & 4.6 & 10.7 & 4.6 & 0.066 & 0.071 & $\begin{array}{c}\text { not } \\
\text { rejected }\end{array}$ \\
\hline $\begin{array}{l}\text { Situation } \\
\text { Control }\end{array}$ & 16.7 & 3.4 & 16.1 & 3.7 & 0.327 & 0.638 & $\begin{array}{c}\text { not } \\
\text { rejected }\end{array}$ \\
\hline $\begin{array}{l}\text { Reaction } \\
\text { Control } \\
\end{array}$ & 16.3 & 3.4 & 16.3 & 3.4 & 0.907 & 0.717 & $\begin{array}{c}\text { not } \\
\text { rejected }\end{array}$ \\
\hline $\begin{array}{l}\text { Positive Self- } \\
\text { instruction }\end{array}$ & 18.1 & 3.6 & 16.8 & 4.0 & 0.032 & 0.128 & $\begin{array}{c}\text { not } \\
\text { rejected }\end{array}$ \\
\hline POS & 14.2 & 2.4 & 13.8 & 2.4 & 0.377 & 0.402 & $\begin{array}{c}\text { not } \\
\text { rejected }\end{array}$ \\
\hline POS 1 & 10.6 & 4.0 & 12.2 & 3.1 & 0.010 & 0.003 & rejected \\
\hline POS2 & 13.5 & 3.5 & 11.7 & 3.5 & 0.002 & 0.002 & rejected \\
\hline POS3 & 16.9 & 3.0 & 16.3 & 3.2 & 0.230 & 0.365 & $\begin{array}{c}\text { not } \\
\text { rejected }\end{array}$ \\
\hline $\begin{array}{l}\text { Need for Social } \\
\text { Support }\end{array}$ & 15.5 & 4.7 & 12.6 & 4.9 & 0.000 & 0.001 & rejected \\
\hline Avoidance & 16.3 & 4.3 & 14.9 & 4.3 & 0.048 & 0.018 & rejected \\
\hline $\begin{array}{l}\text { Escape } \\
\text { Tendency }\end{array}$ & 8.9 & 4.0 & 8.2 & 3.9 & 0.318 & 0.361 & $\begin{array}{c}\text { not } \\
\text { rejected }\end{array}$ \\
\hline Perseverance & 12.0 & 5.8 & 11.1 & 4.7 & 0.340 & 0.355 & $\begin{array}{c}\text { not } \\
\text { rejected }\end{array}$ \\
\hline Resignation & 8.1 & 3.7 & 7.2 & 3.6 & 0.108 & 0.095 & $\begin{array}{c}\text { not } \\
\text { rejected }\end{array}$ \\
\hline Self-Accusation & 11.0 & 4.5 & 9.9 & 4.1 & 0.132 & 0.102 & $\begin{array}{c}\text { not } \\
\text { rejected }\end{array}$ \\
\hline NEG & 10.0 & 3.7 & 9.1 & 3.2 & 0.113 & 0.075 & $\begin{array}{c}\text { not } \\
\text { rejected }\end{array}$ \\
\hline
\end{tabular}

Source: Date source - the authors' own calculations

Differences in adaptive behaviour of males and females in the situations of increased study load associated with the military university studies and the stress analysis are identified in relation to the utilization rate of a given strategy. The pvalue of the two-sample test was lower than 0.05 for Underestimation, Guilt Rejection, Diversion, Need for Social Support, Avoidance, POS1 and POS2. At a significance level of 0.05 , a difference between males and females was proved in these strategies. In females, there was, in terms of statistics, a significantly higher utilization rate in the Diversion, Need for Social Support, Avoidance and POS2 strategies. On the other hand, in terms of statistics, a significantly higher utilization rate of the Underestimation, Guilt Rejection and POS1 strategies was found in males. 
Table 5: Identification of the strategy utilization rate between the fields of the Faculty of Leadership and the Faculty of Military Technology

\begin{tabular}{|c|c|c|c|c|c|c|c|}
\hline \multirow[t]{2}{*}{ Strategies } & \multicolumn{2}{|c|}{ FVT } & \multicolumn{2}{|c|}{ FVL } & \multirow{2}{*}{$\begin{array}{c}\text { t-test } \\
\begin{array}{c}\mathrm{p}- \\
\text { value }\end{array}\end{array}$} & \multirow{2}{*}{$\frac{\text { M-W }}{\begin{array}{c}\mathrm{p}- \\
\text { value }\end{array}}$} & \multirow{2}{*}{$\begin{array}{c}\text { Decision } \\
\text { on } \mathbf{H 3}_{0}\end{array}$} \\
\hline & Mean & SD & Mean & SD & & & \\
\hline Underestimation & 13.2 & 4.5 & 13.1 & 4.6 & 0.809 & 0.918 & $\begin{array}{c}\text { not } \\
\text { rejected }\end{array}$ \\
\hline Guilt rejection & 11.0 & 3.5 & 10.6 & 3.8 & 0.357 & 0.623 & $\begin{array}{c}\text { not } \\
\text { rejected }\end{array}$ \\
\hline Diversion & 12.8 & 3.6 & 13.1 & 3.6 & 0.426 & 0.431 & $\begin{array}{c}\text { not } \\
\text { rejected }\end{array}$ \\
\hline $\begin{array}{l}\text { Substitutional } \\
\text { Satisfaction }\end{array}$ & 10.9 & 4.9 & 11.0 & 4.4 & 0.848 & 0.715 & $\begin{array}{c}\text { not } \\
\text { rejected }\end{array}$ \\
\hline $\begin{array}{l}\text { Situation } \\
\text { Control }\end{array}$ & 16.1 & 3.9 & 16.3 & 3.4 & 0.583 & 0.627 & $\begin{array}{c}\text { not } \\
\text { rejected }\end{array}$ \\
\hline $\begin{array}{l}\text { Reaction } \\
\text { Control }\end{array}$ & 16.7 & 3.6 & 16.1 & 3.3 & 0.240 & 0.246 & $\begin{array}{c}\text { not } \\
\text { rejected }\end{array}$ \\
\hline $\begin{array}{l}\text { Positive Self- } \\
\text { instruction }\end{array}$ & 17.2 & 4.1 & 17.0 & 3.9 & 0.663 & 0.762 & $\begin{array}{c}\text { not } \\
\text { rejected }\end{array}$ \\
\hline POS & 14.0 & 2.3 & 13.8 & 2.4 & 0.632 & 0.971 & $\begin{array}{c}\text { not } \\
\text { rejected }\end{array}$ \\
\hline POS 1 & 12.1 & 3.3 & 11.8 & 3.3 & 0.499 & 0.993 & $\begin{array}{c}\text { not } \\
\text { rejected }\end{array}$ \\
\hline POS2 & 11.9 & 3.7 & 12.1 & 3.4 & 0.683 & 0.569 & $\begin{array}{c}\text { not } \\
\text { rejected }\end{array}$ \\
\hline POS3 & 16.5 & 3.2 & 16.4 & 3.1 & 0.758 & 0.912 & $\begin{array}{c}\text { not } \\
\text { rejected }\end{array}$ \\
\hline $\begin{array}{l}\text { Need for Social } \\
\text { Support }\end{array}$ & 13.0 & 4.6 & 13.3 & 5.2 & 0.673 & 0.595 & $\begin{array}{c}\text { not } \\
\text { rejected }\end{array}$ \\
\hline Avoidance & 14.9 & 4.1 & 15.3 & 4.5 & 0.488 & 0.217 & $\begin{array}{c}\text { not } \\
\text { rejected }\end{array}$ \\
\hline $\begin{array}{l}\text { Escape } \\
\text { Tendency }\end{array}$ & 8.1 & 3.8 & 8.5 & 3.9 & 0.445 & 0.297 & $\begin{array}{c}\text { not } \\
\text { rejected }\end{array}$ \\
\hline Perseverance & 11.4 & 4.7 & 11.2 & 5.1 & 0.759 & 0.547 & $\begin{array}{c}\text { not } \\
\text { rejected }\end{array}$ \\
\hline Resignation & 7.3 & 3.4 & 7.4 & 3.8 & 0.859 & 0.920 & $\begin{array}{c}\text { not } \\
\text { rejected }\end{array}$ \\
\hline Self-Accusation & 10.3 & 4.4 & 10.0 & 4.0 & 0.614 & 0.389 & $\begin{array}{c}\text { not } \\
\text { rejected }\end{array}$ \\
\hline NEG & 9.2 & 3.1 & 9.3 & 3.4 & 0.884 & 0.886 & $\begin{array}{c}\text { not } \\
\text { rejected }\end{array}$ \\
\hline
\end{tabular}

Source: Date source - the authors' own calculations

No statistically significant difference between FVL and FVT in any of the strategies was found. All p-values were higher than 0.05 as presented in table 5 . In relation to the values of utilization rate of a given strategy, it was found that they are the same for the fields of the Faculty of Military Leadership and the Faculty of Military Technology. We do not reject the null hypothesis - the mean values (population medians) of the utilization rate of each strategy for the fields of the Faculty of Military Leadership and the Faculty of Military Technology are the same.

\section{DISCUSSION}

The implemented pilot study contributed to the research of military study load in several directions. At the knowledge level, it brought arguments in support of the claim that the core of this burden in current generations of military students no longer lies solely in the area of managing military activities and the demands of military training.

The highest values of the perceived stress intensity related to the military study load are reported within the School Regiment, which is also related to the values in the area of Military Duties / Matters. Thus, as the most marked area the students identified the situations related to military matters, primarily to the institution and the personnel that determine military responsibilities, not academic ones. This is also confirmed by the analyses of information flows in a given facility, which were performed within the framework of the Leadership course in the $4^{\text {th }}$ year, which is aimed at the development of communicative competency [61]. Setting more effective systems of communication among individual bodies involved in the educational process of military students and training of the military personnel in teaching and working with students can be an alternative for reducing the perception of stress intensity in this area.

The study confirmed the finding that the area of Military Training in Field Training in the Březina Military Training Area is not perceived as significant [62]. Even in this study, it is not overestimated - it does not show and exceed the values in the areas of military study load in the academic environment.

The obtained results and the method of their processing point to the fact that the mean values of stress intensity in the given areas of the study load must be viewed with caution since the mean value of the given area is the arithmetic mean of all situations that the given area represents. For more accurate interpretation and characterization of the real study load it is necessary to analyse specific stressful situations not only from the viewpoint of the intensity of perceived study load, but also from the viewpoint of the frequency of occurrence.

The second highest stressor was the area of School Assessments. The respondents' statements partly correspond with the results of previous researches [12] [63] [64] where the areas of Learning Process Conditions and School Assessments were evaluated using the higher mean values than others, which reflected the intensity of perceived stress. This level of perceived stress is absolutely understandable in the context of the study load. The intensity of perceived anxiety is also reflected in the values in the individual items of a given area (table 2). In addition, negative emotions of the military students are accentuated by the impossibility of choosing a specialization - the military occupational speciality of the officer at the beginning of their studies ${ }^{4}$.

This discomfort of the study load within the 2014 study program, when students were divided into study modules after the $3^{\text {rd }}$ year of studies, was mitigated in the 2019 study

\footnotetext{
${ }^{4}$ Students are admitted to a military university without knowing their future specialization in the officer corps of the Army of the Czech Republic for combat units (e.g. combined-arms commander, commander of artillery, reconnaissance or chemical units) or in battalion headquarters staffs (e.g. military logistics, financial or human resource management, and information resource management).
} 
program by adopting the measures for the division into modules after the $1^{\text {st }}$ year of studies. We will be able to make certain of the functionality of the measure in the current academic year 2019/2020. However, there is no change in the fact that the training for a given specialization in most cases (except for military occupational specialities - pilot, and chemical unit commander) will not start until the $4^{\text {th }}$ year of studies.

The lowest intensity of perceived stress was found out in the area of Learning Process Conditions. The second lowest indicator was the area of Other Factors. The students of the University of Defence (physical and social environment) perceive the conditions of the learning process in terms of the stress intensity as the least stressful. According to their statements, the students assess negatively especially the moves among the individual learning blocks, which is included in the area of Other Factors. It is a fact that has been discussed at the University of Defence for a long time, but due to the location of individual buildings, it is not susceptible to influence.

The contribution of the study in the field of methodology is not negligible. For the needs of the research, a self-designed questionnaire had to be created to cover the areas and factors of study load characteristic of a military university environment. The individual areas of the research (A: Teacher - Student Relationship, B: School Assessments, C: Military Training - C1 Field Training, C2 Military Duties / Matters, D: Learning Process Conditions, E: Students' Interpersonal Relationships, F: School Regiment, G: Other factors) have been verified in assessing 103 situations in individual areas of a study load. It turned out that it is necessary to evaluate it not only for entire areas, but also for individual items, which allow you to specify the real burden in more detail and then more precisely target measures to reduce it. For use in other years of study, it must be revised so that the items correspond to the real situation of the respondents. The questionnaire was found to be a suitable tool for identifying basic events that are in terms of the intensity of perceived stress at the beginning of military university studies as the most stressful, provided that the survey will be conducted at the end of the semester, after completing all key activities, including military training in within the subject - Preparation in the field.

Although military higher education has its peculiarities, as mentioned in Part 1 of this article, a number of commonalities with civilian university students have been found in military student workload management strategies. Of the individual strategies, military students most preferred the active strategy of positive Self-instruction, followed by the strategy Situation Control and Reaction Control, which can be considered a favourable trend. According to one of the latest researches in the Czech Republic (a sample of 263 respondents, the average age -23.85 years) from more than ten universities it has been found out that of the positive strategies the Situation Control strategy prevailed by the civilian students and the proven difference in the use of positive and negative strategies for the stress management was not so considerable [6]. We place these ways of stress management among the positive - active strategies that reduce stress and are very constructive, useful and desired strategies in the Army. According to the older researches that dealt with the study of coping strategies in Czech university students, the solution of the problem, cognitive restructuring and social support were the most preferred. On the contrary, avoidance and social isolation were mentioned least [44].

Resignation and Escape Tendency fell into the least used strategies. They rank among the negative ones, which tend to maintain or intensify stress within the meaning postponing the problem / activity - procrastination.

The greatest differences between the approximate comparison and the outcomes of military students were noted in the Avoidance strategy. This strategy cannot be categorized as a positive or negative coping strategy. As compared with the general population, military students - males - used the strategy of Social Support less and the strategy of Avoidance more [65]. In contrast to the general population, military female students used the strategy of Social Support, Positive Self-instruction, and the strategy of Reaction Control more according to males.

The results of previous researches show relatively large differences between girls and boys not only in perception of stress, but also in the choice of coping practices [57] [66] [67]. Even if the military profession prefers equal opportunities for males and females, where there is no distinction between them when accepting physiological dispositions of genders in the preparation, training and performance of tasks, differences were found in some coping strategies in males and females.

In females, in terms of statistics, a significantly higher utilization rate of strategies such as Diversion, Need for Social Support, Avoidance and POS2 was ascertained. On the other hand, in term of statistics, a significantly higher utilization rate of the Underestimation, Guilt Rejection and POS1 strategies was found out in males. The gender differences in the management of study load cannot be ignored in the military environment, as also shown by the results of an empirical research probe dealing with sexual differences in the perception of study load and in the choice of coping strategies. Here, the stressed students evaluated the study load as higher than the burden of life at all. The inclinations and aspects given by genders significantly contributed to the selection of coping strategies [68].

\section{CONCLUSIONS}

In conclusion, it should be noted that the main aims of pilot study were fulfilled. It helped to create theoretical background and a set of tools to address part of the specific research related to the military study load. At the same time, it laid the foundations for the prepared longitudinal study, the result of which will be an overview of the most frequently used strategies for managing the study load of students of individual faculties and their possible changes during the first three years of study. The study assumes a mixed research design - 
supplementing the used quantitative methods with structured interviews with selected students for a deeper analysis of the nature of the workload and the strategies used. Such a research concept should provide a sufficiently detailed analysis of the educational environment, from which it would be possible to more accurately derive the factors affecting the study load and formulate factual recommendations for all entities involved in creating the study load and assistance in managing it at the University of Defence. It is only the basis which will serve to reduce the early termination of studies of soldiers.

The study succeeded in proving that the military study load for the addressed students in the first year of study is not exclusively caused by the demands of military training, but is directed to the non-academic area, specifically to organize the military way of life at a particular military university. This fact can cause the accumulation of negative emotions in individuals and this, combined with the low sensitivity of the military environment to the emotions of the individual, can become a risk factor leading to student failure in coping with the study load. Important areas are also the area of student performance evaluation - School Classification and Military Training. Therefore, these reasons should logically be directed by the important reasons given by students for early termination of military studies and they should also be significantly affected by measures preventing an increase in the number of prematurely completed studies.

In relation to workload management strategies, it has been found that a number of findings from previous research and studies of the problem conducted at other Czech and foreign universities can be applied in the military environment, taking into account the differences between the military tertiary education system and the personality of the military student. The identified preference for positive strategies for managing the study load is in line with the needs of the military environment, but it is not sufficient for the final management of the study load.

The important factor in coping with the study load is motivation according to the HEDOCE Europe-wide 2015 study [69]. The individual's ability to cope with the obstacles presented by the study load presented to him, especially if this happens over a longer period of time, requires the will of the individual and his ability to strengthen it. Research on military study workload should be supplemented by finding out the motivation of respondents to study, but also to perform in general. In the case of the University of Defense, it would be interesting to find out whether incentive measures such as scholarships, one-off rewards for school representation or recently introduced lessons - Mentors' meetings, where students have the opportunity to alert a mentor to possible study difficulties, really have a motivating effect.

Although the concrete results have primarily local validity, the authors see its benefits for the wider academic environment mainly in two areas: methodological and cognitive. In the methodological area, it is the creation of the Questionnaire of Stressful Situations for the Military University Environment and the verification of its validity. This tool will also be used in the mentioned specific research to obtain relevant data from foreign military universities and, after appropriate modifications, can also be used for the civilian university environment. In the field of knowledge, it can be considered important to find that for current students of a military university, the core of the study load may lie in completely different areas than other subjects interested in their education. From this it can be deduced that research of study load in a specific group of students and at the level of tertiary education can provide management with essential information for qualified decisions about changes in the educational process aimed at reducing the study load.

\section{ACKNOWLEDGMENT}

The article has been developed as part of the Specific Research of the Ministry of Education, Youth and Sports entitled Experience of Foreign Military Universities with Early Termination of Studies (SV19-FVL-K104-FED). In addition to the project, it is assumed that the results will be used to innovate the educational programs for the military study and the development of the dissertation thesis entitled Specifics of Coping with the Study Load by the Students of the University of Defence.

\section{References}

[1] V. Švec, G. Koláčková, "Teoretická východiska problematiky retence vysokoškolských studentů," AULA, vol. 21, no. 2, 2013, pp. 56-69.

[2] L. Menclová, J. Baštová, K. Kronrádová, "Neúspěšnost studia posluchačů 1. ročníků technických studijních programů veřejných vysokých škol v České republice a její příčiny," Centrum pro studium vysokého školství, 2003.

[3] V. Švec, I. Tichá, "Retention issue of the Czech colleges' students," Essentia, vol. 8, 2007, pp. 1-8.

[4] A. Vlk, J. Drbohlav, T. Fliegl, V. Hulík, Š. Stiburek, V. Švec, Studijní neúspěšnost na vysokých školách: Teoretická východiska, empirické poznatky a doporučení. Prague: Slon, 2017.

[5] J. M. Safranková, M. Sikyr, "The study of university students' motivation," International Journal of Teaching and Education, vol. IV (4), 2016, pp. 48-59.

[6] V. Jeřábková, "Vztah dispoziční optimism / pesimizmu, copingových strategií, míry úzkosti a prožívaného stresu studentů vysokých škol," Dissertation. Brno: Masaryk University, 2016.

[7] G. B. Moneta, M. M. Spada, F. M. Rost, "Approaches to studying when preparing for final exams as a function of coping strategies," Personality and Individual Differences, vol. 43, no. 1, 2007, pp. 191-202.

[8] J. P. Bean, S Eaton, "A psychological model of college student retention, in Reworking the departure puzzle: New theory and research on college student retention," J. M. Braxton, Ed. Nashville, TN: Vanberbilt University Press, 2000, pp. 48-61. 
[9] A. Seidman, "Minority student retention: Resources for practitioners," New Directions for Institutional Research, vol. 2005, March 2005, pp. 7-24.

[10] H. Quinn (2002). Should I stay or should I go? - A study on early leavers. In: Phoenix-The AGCAS Journal. Association of Graduate Careers Advisory Services. Available: http://www.agcas.org.uk/publications/phoenix/ autumn_2002/should_i_stay.htm

[11]M. Ramachandiran, S. Dhanapal, "Academic stress among university students: A quantitative study of generation Y and Z's perception," Pertanika Journal of Social Sciences and Humanities, vol. 26, no. 3, September 2018, pp. 2115-2128.

[12]M. Labajová, "Perception of School Stress related to School Climate," Dissertation. Olomouc: Palacký University, 2011, pp. 184.

[13]M. Mouralová, A. Tomášková, "Studijní neúspěšnost na českých vysokých školách a důvody, které k ní vedou,“ AULA, vol. 15, no. 1., 2007, pp. 16-26.

[14]P. Kutal, "Copingové strategie vojáků AČR," Bachelor thesis. Olomouc: Palacky University, 2011.

[15] R. Honzek, "Stres u př́slušníků bojových jednotek AČR," Bachelor thesis. Olomouc: Palacký University, 2015.

[16]ECTS, Diploma Supplement. Available: https://www. vske.cz/

[17] J. Fedorková, I. Nekvapilová, "Study coping strategies et the tertiary level of education," in 2019 13th International Technology, Education and Development Conf., pp. 8650-8658.

[18]X. Liu, S. Ping, W. Gao. (2019, August). Changes in Undergraduate Students' Psychological Well-Being as They Experience University Life. Environmental Research and Public Health. [Online]. 16 (16). Available: https://www.ncbi.nlm.nih.gov/pmc/articles/PMC6719208/

[19] P. Pedrelli, M. Nyer, A. Yeung, C. Zulauf, T. Wilens. (2015, October). College Students: Mental Health Problems and Treatment Considerations. Academic Psychiatry. [Online]. 39 (5). pp. 503-511. Available: https://doi.org/10.1007/s40596-014-0205-9

[20]K. Paulík, Psychologie lidské odolnosti. 2nd ed. Prague: Grada, 2017, ch. 2.

[21] J. Mareš, J. Průcha, E. Walterová, Pedagogický slovník: Nové rozširrené a aktualizované vydání. $7^{\text {th }}$ ed. Prague: Portál, 2019.

[22] W. F. Hodges, J. P. Felling, "Types of stressful situations and their relation to trait anxiety and sex," Journal of Consulting and Clinical Psychology, vol. 34, no. 3, 1970, pp. 333-337. [Online]. Available: https://doi.org/10.1037/ h0029270

[23] M. B. Youngman, "Some determinants of early secondary school performance," British Journal of Educational Psychology, vol. 50, 1979, pp. 43-52.

[24] M. Havlínová et. al., Program podpory zdraví ve škole: rukovět' projektu Zdravá škola. 1st ed. Praha: Portál, 1998.

[25] J. Křivohlavý, Psychologie zdraví. 1st ed. Praha: Portál, 2001.

[26] J. Praško. Poruchy osobnosti. Praha: Portál, 2003.
[27]L. Medveděvová, "Rodové odlišnosti a vývinová dynamika školských stresorov v ranej adolescenci," Psychológia a patopsychológia diet'ata, Bratislava: Slovak Academic Press, vol. 43, no. 4, 2008, pp. 287306.

[28]I. Binarová, “Období dospívání. Období adolescence,” in J. Šimíčková-Č́ižková, Přehled vývojové psychologie, Olomouc: Palacký University, 2005.

[29]I. Plevová, E. Urbanovská, "Psychická zátěž u dětí a mládeže ve školním prostředí I," in Vědy o člověku na prahu 3. tisíciletí-sborník. Olomouc: VUP, 2002.

[30] I. Plevová, E. Urbanovská, I. Binarová et al., "Vnímání školní zátěže vzhledem $\mathrm{k}$ věku, pohlaví a míře sebevědomí," in Antropologicko - psychologický pohled na populaci regionu - sbornik, Olomouc: VUP, 2005, pp. 107-115.

[31] M. Öhrstedt, P, "Lindfors. Linkages between approaches to learning, perceived stress and expected and actual academic outcomes among first-semester psychology students," Journal of further and higher education, vol. 42, no. 1, 2018, pp. 116-129.

[32]L. I. Schmidt, M. Sieverding, F. Scheiter, J. Obergfell, "Predicting and explaining students' stress with the Demand-Control Model: does neuroticism also matter?," Educational psychology: an international journal of experimental educational psychology, vol. 35, no. 4, 2015, pp. 449-465.

[33] R. S. Lazarus, S. Folkman. Stress appraisal, and Coping. New York: Springer, 1984.

[34] W. Janke, G. Erdmannová, Stress Management Strategy, Prague: Testcentrum, 2003, ch. 1.

[35]R. S. Lazarus, S. Folkman, (1984), "Stress, appraisal and coping," New York Springer, in Psychologie, S. Kassin, Ed. Prague. Computer Press, 2007.

[36]E. Urbanovská, Škola, stres a adolescent. 1 st ed. Olomouc: Palacky University, 2010, pp. 38-43.

[37] M. Staempfli, "Adolescent Playfulness, Stress Perception, Coping and Well Being," Journal of Leisure Research. [Online]. 39 (3), 2007, pp. 393-412. Available: htp:// www: <lin.ca/Uploads/cclr11/CCLR11-143.pdf>

[38] V. Kebza, Psychosociální determinanty zdraví, Prague: Academia, 2005.

[39]R. S. Lazarus, Stress and emotion: A new synthesis. New York: Springer, 1999.

[40] J. W. Pennebaker, Opening up: The healing power of confiding in others, New York: William Morrow, 1990.

[41] A. Aldao, S. Nolen-Hoeksema, S. Schweizer, "Emotionregulation strategies across psychopathology: a metaanalytic review," Clin Psychol Rev, vol. 30, no. 2. March 2010, pp. 217-237.

[42] S. Nolen-Hoeksema, "Responses to Depression and Their Effects on the Duration of Depressive Episodes,".Clin Psychol Rev, vol. 100, no. 2. November 1991, pp. 569582.

[43] J. Křivohlavý, Psychologie zdraví, Praha: Portál, 2001.

[44] M. Blatný, L. Osecká, "Zdroje sebehodnocení a životní spokojenosti: osobnost a strategie zvládání," Československá psychologie, vol. 42, 1998, pp. 385-394. 
[45] V. Jeřábková, "Úspěšnost a spokojenost vysokoškolského studenta a jejich souvislost sosobnostními," Dissertation. Brno: Masaryk University, 2016.

[46] M. Vavricová, "Súčasné trendy vo výskume zvládania stresu," Československá psychologie, vol. 57, no. 2, 2013, pp. 134-143.

[47] L. G. Aspinwall, A. MacNamara, "Taking positive changes seriously," Cancer Supplement, vol. 104, 2005, pp. 2549-2556.

[48] S. Folkman, J. T. Moskowitz, "Positive affect and the other side of coping," American Psychologist, vol. 55, 2000, pp. 745-774.

[49] S. Folkman, J. T. Moskowitz, "Coping: Pitfalls and promise," Annual Review of Psychology, vol. 55, 2005, pp. 647-654.

[50]L. G. Aspinwall, A. Clark, "Taking positive changes seriously: toward a positive psychology of cancer survivorship and resilience," Cancer, vol. 104, 2005, pp. 2543-2645.

[51]S. Folkman, "Positive psychological states and coping with severe stress," Social Science and Medicine, vol. 45, 1997, pp. 1207-1221.

[52] V. Svoboda (2020, May). [Online]. Available: https:// www.idnes.cz/xman/rozhovory/stres-nervy-psychologie. A200221 150548 xman-rozhovory rik

[53] B. D. Raffety, R. E. Smith, J. T. Ptacek, "Facilitating and debilitating trait anxiety, situational anxiety, and coping with an anticipated stressors: A process analysis," Journal of Personality and Social Psychology, vol. 72, 1997 pp. 892-906.

[54]D. J. Gallagher, "Personality, coping and objective outcomes: Extraversion, neuroticism, coping styles and academic performance," Personality and Individual Differences, vol. 21, no. 2, 1989, pp. 267-283.

[55]F. Baumgartner, “Zvládání stresu - coping,” in: J. Výrost, I. Slaměník, Aplikovaná psychologie II, Prague: Grada Publishing, 2001.

[56] R. W. Shiraishi, C. M. Aldwin, (2004), "The development of coping from young adulthood to midlife," in. C. M. Aldwin. Stress, coping, and Development. New York: The Guilford Press, 2007.

[57]M. Hanžlová, P. Macek, "Zvládací strategie a styly dospívajících," Psychológia a patopsychológia dietat'a, vol. 43, 2008, pp. 3-22.

[58] G. B. Moneta, M. M. Spada, F. M. Rost, "Approaches to studying when preparing for final exams as a function of coping strategies," vol. 43, 2007, pp. 191-202.

[59] W. Janke, G. Erdmannová, Stress Management Strategy, Prague: Testcentrum, 2003, ch. 1.

[60] R. S. Lazarus, S. Folkman. Stress appraisal, and Coping. New York: Springer, 1984.

[61] J. Vlašín, "Causes of early dropout of the military students and educational improvements at the University of Defence," Dissertation. Brno: University of Defence, 2015.

[62] E. Kozáková, R. Saliger, "Identification of stressors of military students", in 2019, 13th International
Technology, Education and Development Conference pp. 6474-6483.

[63]E. Urbanovská, "Citlivost náctiletých ke školní zátěži," School and health, vol. 21, no. 2, E. Rehulka et. al., Brno: Paido, 2007, pp. 257-272.

[64]E. Urbanovská, “Školní stresory - frekvence výskytu ve srovnání s intenzitou jejich působení, "Aktuálne otázky pedagogiky a psychológie III, Banská Bystrica: FHV UMB, 2008, pp. 212-224.

[65]R. Pospíšil, R. Mitáček, T. Zeman, P. Macháčková, B. Ptáček, "Coping Strategies of Military Students in the Army of the Czech Republic," in 2018 the 32th International Business Information Management Association Conference, pp. 2099-2106.

[66]E. Ficková, "Preferovanie copingových stratégií vo vzt'ahu k rôznym problémom detí a adolescentov," Psychológia a patopsychológi diet'at'a, vol. 30, no. 1, 1995, pp. 87-92.

[67] L. Medved’ová, “Zdroj stresu a zdroje jeho zvládania det'mi a adolescentmi: Skúmanie zvládania vo VÚDPaP-e v rokoch 1999-2002," Psychológia a patopsychológia diet'at', vol. 39 (2-3), 2004, 108-120.

[68]K. Paulík, Psychologické aspekty zvládáni zátěže, University of Ostrava, Faculty of Arts, 2012.

[69] Š. Stiburek, A. Vlk, "Studijní neúspěšnost na vysokých školách: nejvyšší čas na změnu," 2018. [Online]. Available: https://perpetuum.cz/2018/01

Jolana Fedorková is a professional soldier - an academic worker at the Department of Leadership at the University of Defence in Brno. She is an academic coordinator for students in the subjects of Leadership and Military Psychology. Her research interests include military psychology - development of soft skills: communication competencies, ethical leadership in the Army of the Czech Republic, personality profiles of soldiers and study coping strategies (e-mail: jolana.fedorkova@unob.cz).

Ivana Nekvapilová is an Associate Professor at at the Department of Leadership at the University of Defence in Brno. She specializes in anthropological philosophy, philosophy of education, applied ethics for management, leadership in civil and military environment and social communication (e-mail: ivana.nekvapilova@unob.cz).

Zdeněk Mikulka is a doctor - an academic worker at the Department of Leadership at the University of Defence in Brno. His academic career focuses especially on ethics, applied (military) ethics, ethical education, ethical leadership and leadership in the Army of the Czech Republic. He is a member of International Society for Military Ethics in Europe (e-mail: zdenek.mikulka@unob.cz). 
Contribution of individual authors to the creation of a scientific article (ghostwriting policy)

Jolana Fedorková organized, executed and carried out the students' questionnaire survey. She was responsible for the parts - discussion and conclusion of the military university research.

Ivana Nekvapilová has implemented the research related students' coping strategies, military higher education (tertiary education) and study load.

Zdeněk Mikulka was answerable for the structural analysis and accuracy calculations.
Creative Commons Attribution License 4.0 (Attribution 4.0 International, CC BY 4.0)

This article is published under the terms of the Creative Commons Attribution License 4.0

https://creativecommons.org/licenses/by/4.0/deed.en_US 